\title{
Endnu en Holberg Bog
}

Rasmus Andersön paa Een-Öe går igen

Af aktuar, dr.polit. Paul Johansen

Tandlæge Langager købte i 1950 på auktionen efter lektor Th. A. Müller et eksemplar af Jacob Bidermans Utopia, Køln 1649, for 21 kr. Holberg har, som han ofte selv har fortalt, benyttet Bidermans bog som kilde for flere af sine arbejder. Jeppe paa Bierget er således skrevet over forskellige af de fortællinger, der indgår i Bidermans bog. I Langagers eksemplar er på bindets inderside skrevet Rasmus Andersön paa Een-Öe, og der findes rundt om i bogen en mængde notater, understregninger, krydser, oversættelser og tilføjelser på dansk, latin og tysk.

Langager mente, at alle disse notater er skrevet af Holberg. Han mente også, at det anførte navn ikke dækker over nogen virkelig person, men er skrevet af Holberg som et spøgefuldt pseudonym i lighed med Hans Mikkelsen og Just Justesen. Langager fremlagde sine argumenter i et privattryk i 1957: Rasmus Andersön paa Een-Öe eller Ludvig Holberg. Teorien vakte megen opsigt. Den lærde verden delte sig i to partier: For og imod. Blandt støtterne var Rigsarkivets overarkivar Erik Kroman, der har gjort rede for sine synspunkter i Acta Philologica Scandinavia, 26. årgang. Også professor Hans Brix gik ind for teorien, medens f.eks. professor Billeskov Jansen ikke lod sig overbevise. Langager samlede i 1977 en del af indlæggene i Den Satiriske Raptus, privattryk i kommission hos Rosenkilde og Bagger. Langagers Utopia er senere erhvervet af Det kongelige Bibliotek som gave fra Carlsbergfonden og Professor Carl Roos' Mindelegat. Den findes i Håndskriftafdelingens Ny kongelig Samling $51264^{\circ}$ sammen med Langagers arkiv, der bl.a. rummer hundredevis af udklip fra diskussionen i aviseme.

For kort tid siden gjorde fuldmægtig Flemming E. Pedersen et fund, der i endnu højere grad vil beskæftige holbergforskere og som vil kaste nyt lys over Langagers bog. Jeg har fået tilladelse til at fremlægge en foreløbig beskrivelse og tolkning af dette fund. 


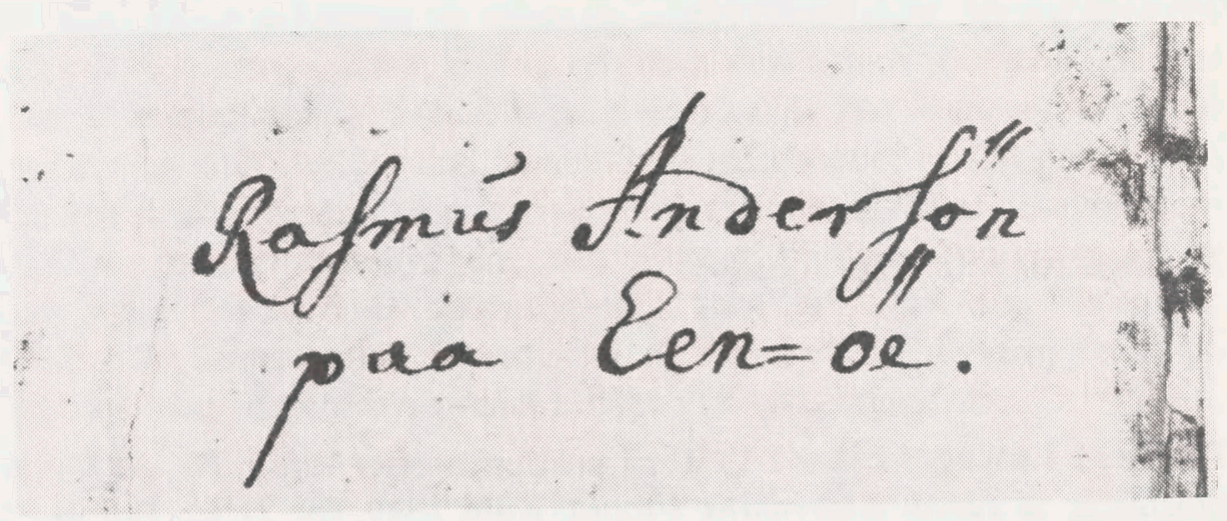

Det drejer sig om et eksemplar af en senere udgave af Bidermans Utopia, trykt i Dillingen 1691 . Begge udgaver er i $12^{\circ}$, og trykket i den sidste (U2) følger nøje trykket i den første (U1). Dog er i U2 udeladt en 10 sider lang tilegnelse til ærkehertug Sigismund af Østrig.

Teksten følges ad i de to udgaver, linie for linie og side for side, undtagen i det allersidste afsnit, hvor teksten i U1 er trukket lidt mere sammen, så den fylder en side mindre end i U2. U1 har en lille trykfejlsliste og begge b $\varnothing$ ger har til slut indholdsregistre, der dog ikke er ens. Ved pagineringen af U1 er side 157 fejlagtigt betegnet som 156 og tallene 183 og 184 er sprunget over. Ved sammenligning af de to bøger efter dette sted svarer et sidetal i U2 altså til et sidetal i U1, som er 2 større. Teksten i U2 slutter på side 394 og indholdsfortegnelsen optager de sidste 10 sider af ark R. U2 er forsynet med et nyt bind omkring år 1800. Det er formentlig ved den lejlighed at arkene D og E er blevet ombyttet, således at siderne 93-116 findes mellem s. $68 \mathrm{og} \mathrm{s}$. 69 . Måske er det ved samme lejlighed at et fantasifuldt kort over Utopia er forsvundet. Det var trykt på det første blad i ark A. Kortet, der er afbildet i Langagers bog s. 41 og som ikke forekommer i de tidligere udgaver, findes $i$ et eksemplar i Universitetsbiblioteket.

Jacob Biderman, der levede 1576-1639, huskes i dansk litteraturhistorie udelukkende som forfatter af Utopia. Det er en samling fabler, anekdoter og historier, som han skrev i 1604, men som først blev trykt efter hans død. Værket består af 6 afsnit - bøger - der er delt i mange kapitler. Bøgerne II-VI er 


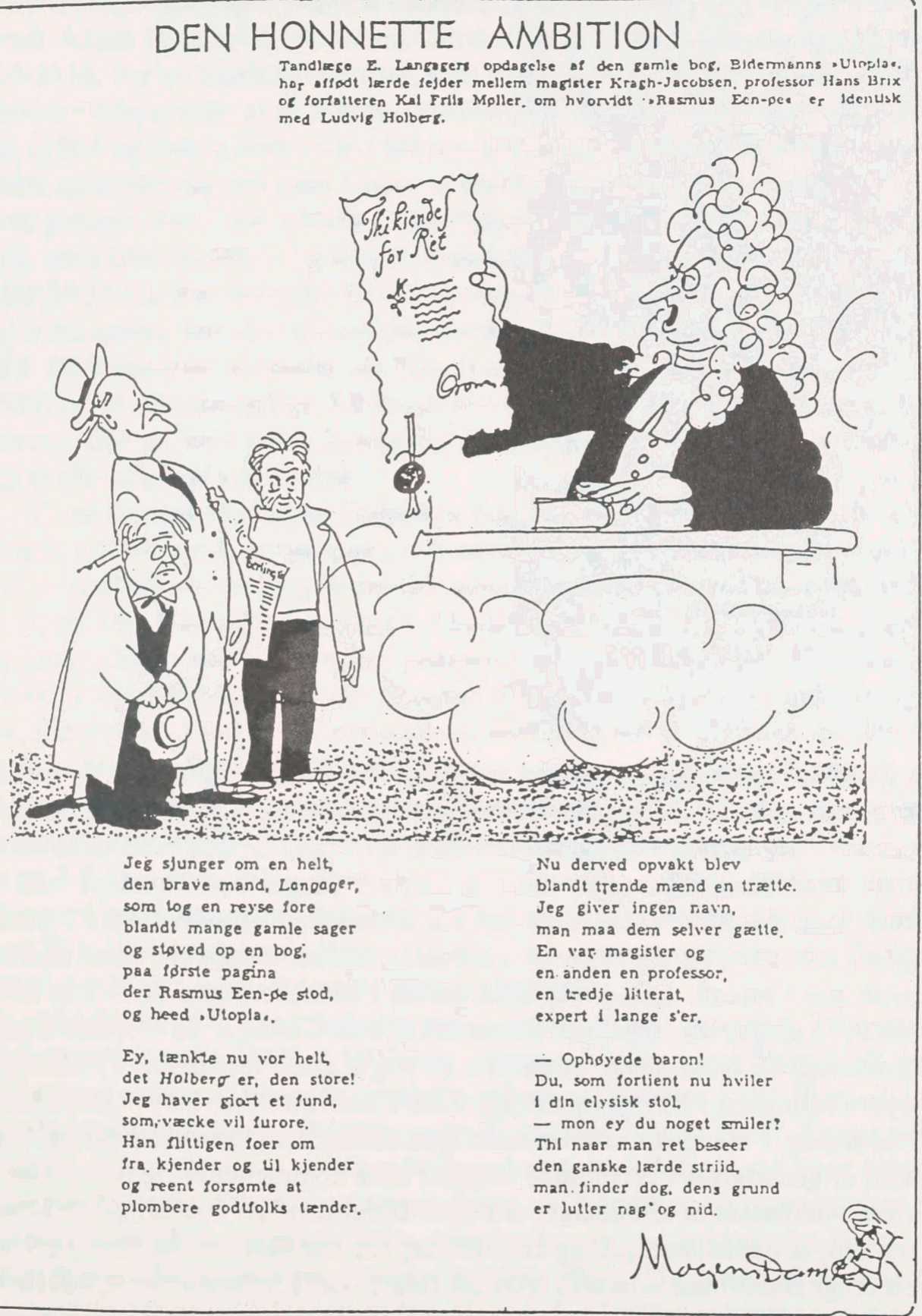

Dagens Nyheder 22. febr. 1957. 
UT T I A

DIDACI BEMARDIN!,

\section{A C O B I \\ BIDERMANI, \\ E Societate Jesu}

SALES MUSICI,

LUDICRA A MIXTIM

2. feria litteratè ac feftivè de-

narrantur.

EDITIO TERTIA,

IIndice rerúmaucta:

Cum Gratia of Privilegio S. C. Majef?.

Et facultrate superioru n.

숭 (*) 웅해

D IINGAS.

apud Joannem Casparum Bencard, Bibliogolam Academicum.

1N.NO X1. DC. ZXXXY.

-

knyttet sammen med en spinkel handling. Tre mænd foretager en rejse til det opdigtede land Utopia og fortæller undervejs hinanden historier og oplever de særeste ting. Det er en lignende ramme som man kender fra Decameron og 1001 Nats Eventyr. I tyske leksika nævnes Utopia kun i forbigående, men Biderman betegnes som tidens største dramatiker. Han indtrådte i jesuitterordenen i 1596, og kort efter at han havde skrevet Utopia blev han ansat som professor i retorik og leder af skoleteatret i München. Her skrev han en lang række skuespil, der betegnes henholdsvis som Comedia og Comico-tragedia. Belisarius og Cenodoxus er titlerne på nogle af de første. Ialt 11 skuespil er trykt i München i 1666 under titlen: Ludi Theatrales Sacri sive Opera Comica Posthuma. I nyere tid er interessen igen rettet mod disse skuespil og flere af dem er genudgivet i reviderede udgaver med kommentarer og noter. Det ville være interessant at unders $\emptyset$ ge, om også Biderman selv har brugt anekdoterne fra Utopia i sine skuespil, og om Holberg har har haft kendskab til og eventuelt brugt Bidermans skuespil, men det falder udenfor rammerne af nærværende undersøgelse. Biderman blev i 1615 kaldet til jesuitteruniversitetet i Dillingen, en lille by i nærheden af München, som professor i teologi. I 1624 kom han til Rom, hvor han blev medarbejder hos en jesuittergeneral. Her levede han til sin død, 15 år senere. 
På det forsatspapir, der ved ombindingen er indsat i U2, er anført ejernavnet Adam Hauch, 1858. Adam Gottlob Øhlenslæger Hauch, der levede 1836-1914, var en kendt skolemand. Han blev student fra Metropolitanskolen i 1854 og erhvervede altså bogen i studietiden. Han bestod sin embedseksamen i 1864 og deltog samme år i krigen. Efter nogle år som lærer ved Søakademiet oprettede han sin egen Latin- og Realskole, som han drev 1872-1890. I denne periode skrev han adskillige lærebøger i latin. Han måtte nedlægge sin skole, men blev derefter knyttet til Katedralskolen i Roskilde, hvor han var rektor 1902-12. Det fremgår ikke af bogen, hvor længe Hauch har beholdt den, men senere har den tilhørt den norske højesteretsadvokat Jonas Skovgaard. På indersiden af bindet har Hauch skrevet, at bogen skal være forfattet i 1604, og at Det kongelige Bibliotek har en udgave fra 1649. Øverst er der skrevet endnu en linie tekst, formentlig før Hauch erhvervede bogen, men den er gjort ulæselig ved udviskning.

Hvad der gør Flemming Pedersens bog så overordentlig interessant er en mængde notater, understregninger, oversættelser og tilføjelser. Mange af notaterne er enslydende med og findes på samme steder i teksten som notaterne $\mathrm{i}$ Langagers bog. Illustrationen viser s. 23 i de to bøger, hvor tilføjelserne ifølge Kromans tydning lyder: Ganea vel ganeum Kippe, Ølkielder eller Horehuusz Hexerie - liderlig forsuppet eller forhoret Knegt. Det ses, at ved ombindingen er et lille stykke af siden i U2 skåret bort, men alligevel er ligheden mellem de to sæt notater ganske forbløffende. Når man ser dem ved siden af hinanden, er der ingen tvivl om, at de er skrevet med den samme hånd. Af disse eksempler, der kan forøges ad libitum, fremgår der klart en sammenhæng mellem de to bøger. I Langagers arkiv findes en brevveksling mellem ham og Jonas Skovgaard om Langagers Utopia og hans teori. Det er besynderligt, at Skovgaard ikke har benyttet anledningen til at slå op i sin egen Utopia, så ville han straks være blevet opmærksom på sammenhængen.

På billedet af s. 23 i U1 finder man nogle krydser i marginen. Tilsvarende krydser findes ikke i U2. I U1 findes sådanne krydser i bog I kap 5-18, der er en større, sammenhængende bondefortælling, og desuden i bog II kap 2-14, hvor den opdigtede rejse begynder, og endelig i bog IV kap 16-27. Det er nøjagtigt de samme afsnit, Langager betegner som hovedafsnit, og hvor begge bøger har de fælles notater med henvisninger til litteraturen og oversættelser af enkelte gloser til et bramfrit dansk, som beskrevet af Langager og Kroman. Det skal med det samme fremhæves, at disse afsnit ikke hører til de dele af Utopia, som har varet kilder til Holbergs arbejder. Langager hæfter sig ganske vist ved, at man i U1 i marginalteksten finder ordene Iter in Utopiam understreget. Det mener han har tilknytning til Niels Klim, skønt Bidermans rejse iøvrigt ikke har meget til fælles med Niels Klims. Man kan ligeså godt mene, 
at understregningen viser, hvor det andet af disse omtalte hovedafsnit begynder med sine krydser og notater. Disse tre hovedafsnit er ved krydserne delt op i ialt omtrent 90 småstykker, der hver omfatter 15-20 linier tekst.

Medens de to sæt notater har en forbløffende lighed, studser man over, at der flere steder er forskelligheder $i$ stavemåden. Ser vi igen på s. 23, læser man i U1 Hore-huusz og Knegt, men i U2 Hoerhuus og Knagt. På s. 8 har vi tilsvarende i U1 sam̃en og i U2 sammen.

Det er naturligt at fremhæve det eneste sted, hvor der i U2 findes en oversættelse til dansk, som ikke forekommer i U1. I IV 46 er ordene Anser turundulis effartus implebat oversat ved En fyldt og stoppet gaaes. I stykket umiddelbart forinden findes også et par latinske notater, som ikke forekommer i U1.

I U2 findes utallige understregede ord, adskillige tusinde. Nogle af understregningerne er foretaget med samme art blæk, som er brugt ved notaterne og som regel eller i hvert fald oftest i tilknytning til disse. Langt størstedelen af understregningerne i U2 og en del lodrette streger i marginen er imidlertid skrevet med rødt. Sådanne røde understregninger forekommer ikke i U1.

Langager mente, at U1 var særligt nært knyttet til Jeppe paa Bierget, til trods for at de af ham navngivne hovedafsnit ligger udenfor Jeppe-stoffet. Rahbek har indgående beskæftiget sig med forholdet mellem Utopia og Jeppe. I Ludvig Holbergs udvalgte Skrifter, bind 6, 1806 giver Rahbek en fri oversættelse af de pågældende afsnit hos Biderman. Han skriver Jeppe for Menalcas og Baronen for fyrsten i Utopia, og så har vi hele handlingen i Jeppe: Den drukne Jeppe lægges i Baronens seng. Han vågner, og han tror, han er i Paradis. Så kommer lakajerne og lægerne, han drikkes fuld igen og vågner op på møddingen. Han dømmes, hænges og benådes igen: skridt for skrift følger man Jeppes handling. På dette skelet har Holberg så digtet videre med Jacob Skomager, Mester Erich, Ridefogdens kone og Jeppes brogede hest plus hele den vidunderlige dialog. Langager anfører s. 22-23, hvilke afsnit af Utopia det drejer sig om. Netop på disse steder er der $i$ U2 foretaget notater, som ikke findes $i U 1$, og som knytter disse stykker sammen. Efter V 33 står der således contin. pag. 281, og V 52 læser man continuatio interruptae historiæ pag. 253254.

Indenfor disse afsnit af U2 finder man omtrent 7000 understregede ord. De tilsvarende afsnit i U1 viser ikke væsentlige tegn på at være benyttet.

Et andet sted i bog V, nemlig i kapitlerne 47-51, finder man ligeledes talrige brugsspor. Omtrent 300 ord er understreget og på s. 274 er et stykke afmærket med en streg i margin. Den latinske tekst af dette afsnit kan man i sammentrængt form gengive således: En forgældet person - vi kan vel kalde ham Leerbeutel - og nogle af hans venner møder en enfoldig bondeknøs. De 


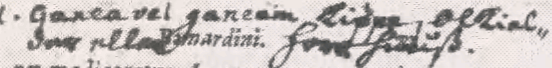

ne medicaretur, In cam fítentus cogitationem ad villam propinquant Sed criam mulier inter hac moram perta$\mathrm{f}$, horas \&. momenta in digitos mirrebat ; cumélue in expectando matico magusm diei partem fruftra fuilet, fubijt fufpicari, virum alicubi fe in ganeastrmmerfile, \& (quod feminis inge- $q \alpha$. niurh eft) continuo ficta pro veris habebat; quare fe aduerfus rediturum armat. Interea fub primam noctis fam cem maritus ab oftio vocat, atque aperiri iubet: Adeft incer primos Villic2, \& ad marirum à via \& mali meta exanguem : ita, inquit, omineste Înfori, inferzque agant helluo ! adecne cerrum tibi eft, wibil mihi, nihil liberis reliqui facere? Villicus y, Led foemina os pugnis occupare,pedibas ferire, \& per capillos lamencantem in cubiculum trahere: Cogit bat interim Rufticus, mulierem fafciois infeftari, aut certè à mente excidille, cum illa identidem vetberandô opprobraret, vi rem fuam Aforas prodegiffet. Abiurare ille, \& $\&$, vrbem fe nunquam ingreflum, colsendere. In mexcatum, inquit illa, nor in popinam mihi, ganeocondixeras. Yixille rander

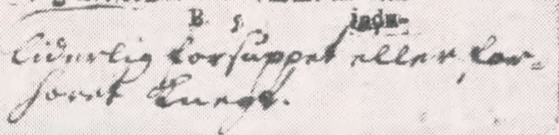

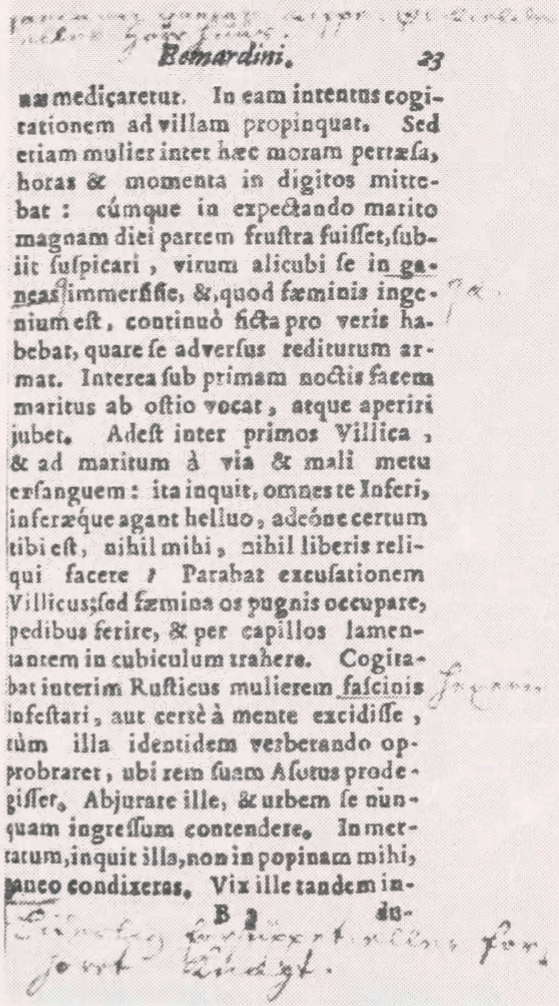

Side 23 i henholdsvis U1 (til venstre) og U2 (til højre).

klæder ham ud som en fornem person, lover ham guld og grønne skove og instruerer ham om, at han skal tale så lidt som muligt og lade alle spørgsmål gå videre til Leerbeutel der skal agere hans hovmester. De indlogerer sig på byens bedste værtshus og forlanger det fineste traktement. De får - på kredit leveret kostbare stoffer og ædle stene og inviterer byens honoratiores til et fyrsteligt gæstebud. Næste morgen, når de handlende kommer for at få deres penge, er Leerbeutel og hans kumpaner stukket af. Den stakkels bondedreng er det eneste pant, de besvegne kan holde sig til. Han må stå til regnskab for bedragerierne. Igen har vi hele stoffet til en Holbergkomedie, kun ændrer Holberg den brutale slutning, så den pantsatte bondedreng slipper med skrækken. Langager afbilder s. 283 i U1 for på dette sted at påvise brugsspor: to accenter over o'er i slutordene i kap. 52. Af gengivelsen af den tilsvarende side 281 i U2 ser man det sidste afsnit om bondedrengen med alle understregningerne, og samtidig ser man en af Jeppe-henvisningerne, for netop her slår Biderman igen over til Menalcas (Jeppes) historie.

Efter denne gennemgang af de to bøger kan man prøve at uddrage, hvad man deraf kan slutte om bøgernes brugere og om deres brug af bøgerne. Lang- 


\section{Bemardini.}

$28 t$

Garciret. Quare miferabiliter illacrihass, capit veftes à fe inimicas projicere \& tonfum verticem emortuis unguibus fulcare;palámque omnibus quis eltes, \& quemadmodum illam perfonam induifet, oftendere. At certè infontera le effe, ac temerè inductum, ut Morso depofito Antiftitem nentirerur. Parcereot ptoin' heminiruftico, neque jubetent furti exortem, fupplicii vadem effe. Prxter hac.lamentis clamoribúfque amnia complebat. Sed creditores obftrspefaćti, poftquam intertrimentum ac. eepiffe fe fenferunt, convitiis in illum debacehati, rapi in vincula in poftorem jufferunt, quem biduó poft Judex, querelis fúsque léry; habitis patibule affixit ? ac ne quis fupplicio tirulus deeffet. hunc appendic litteris Romauis, antiquis fcripeum: Lver LAeruro, QuzPugaAvit Dolo.

$\mathrm{H} x c$ ubi accufator ingenti garrulitate recenfuit, concio frequens exclamat, \& bujus impotor is haud difpar crimen effe:as niti Menalcas fiamnare. tur, impunè quem vis in regio ornatu natio $B S$ peccaturum. Conferunt mos capita in foum wer fe judices, prextoríque tabulam fug. Jupplicion gerunc. In quam dum ille funetum $n m$. confinceratio interrm t Tor.
Side 281 i U2.

Understregningen under MENALCAS er en henvisning til Jeppes historie.

ager har allerede været inde på den tanke, at U1 kan have været brugt til undervisning. Hans Brix tilsluttede sig den tanke, se f.eks. Endrede Signaler, Berlingske Aftenavis 27. Februar 1957. Tanken synes også fuldstændig bekræftet ved sammenligningen mellem de to bøger. Krydsene må have angivet laengden af den enkelte lektion. Læreren har, først i sin egen bog og derefter i elevens, givet visse henvisninger og angivet gode, kærnefulde oversættelser af enkelte ord. Den eneste danske oversættelse udenfor de tre hovedafsnit kan forklares ved, at læreren har forberedt endnu et undervisningsafsnit, men at undervisningen er blevet afbrudt her. De mærkelige varianter i stavemåden tyder vel på, at der er gået i hvert fald nogen tid, mellem læreren skrev notaterne i sit eget eksemplar og i elevens. Men desuden må man mene, at lareren, til trods for at han er en højt kvalificeret latinlarer, har et noget usikkert forhold til dansk retskrivning. Det kan bestyrke Langagers teori om, at det er Holberg, det drejer sig om. Han havde aldrig gået i en dansk skole, og hans ortografi er ofte noget vaklende. 
At U1 har undgået branden i 1728 er herefter ingen gåde. Bogen har været $\mathrm{i}$ elevens besiddelse, og han har jo ikke nødvendigvis boet i København på brandens tid. Den bog med krydsene må nemlig være elevens eksemplar, læreren behøvede ikke sådanne mærker. Det forklarer også, at U1 udelukkende eller så godt som udelukkende bærer brugsspor i de til latinundervisningen benyttede begrænsede stykker, medens U2 også har tjent andre formål. Hvis de tilføjede rammer omkring Jeppe-afsnittene er skrevet med samme hånd som de fælles notater - og det synes at være tilfældet - og hvis det er den samme bruger, der har tilføjet alle de mange røde mærker ved Jeppe og Den pantsatte Bondedreng, så tyder det på, at U2 er Holbergs eget eksemplar af Utopia, den bog han har benyttet ved udarbejdelsen af sine komedier.

Hvis nu læreren var Holberg, hvem var da eleven, der læste latin efter Bidermans bog? Langager, der gik ud fra, at hans bog havde været Holbergs, gjorde sig forgæves anstrengelser for at finde ud af, hvornår bogen efter Holbergs død var kommet i Abraham Lehns besiddelse. Nu må vi imidlertid antage, at bogen ikke var Holbergs, men elevens. Hvad er da nærmere end at antage, at bogen har tilhørt Abraham Lehn lige fra hans unge dage, med andre ord at det var ham, der laeste latin hos Holberg.

Abraham Lehn er født i 1701. Begge hans forældre døde, da han endnu var ganske ung, og efterlod ham en meget betydelig formue. Han kom i huset hos en slægtning, købmand Chr. Schupp i København og fik magister P.B. Mygind, den senere landsdommer, som mentor. Han blev privat dimitteret til Universitetet og bestod examen artium den 30 . december 1717, da han endnu kun var 16 år gammel.

Mylius og den 6 år ældre Holberg kendte hinanden. Holberg har benyttet nogle optegnelser af Mylius ved udarbejdelsen af sine historiske skrifter. I tidsrummet fra sommeren 1716, da Holberg kom hjem fra Rom, indtil december 1717, hvor han blev fast ansat som professor, har han siddet meget småt $\mathrm{i}$ det. Mylius har let kunnet overtale ham til at give den unge elev en sidste afpudsning af latinen inden eksamen. Det blev til de 90 lektioner, der er angivet ved krydsene i Langagers bog.

Af gengivelsen af titelbladet af U2 vil man se, at der nederst under årstallet er skrevet et H. Det er skrevet for længe siden, men det er næppe muligt at sige, om det er ligeså gammelt som bogens noter. Det er imidlertid ikke Hauchs skrift. Kan det være Holbergs? Jeg vover ikke at påstå, at der er Holbergs ejermærke, men det kan nu godt ligne forbogstavet $i$ hans underskrift på de tidligste af hans bevarede breve. Dog kan man jo finde mange andre ejernavne, der begynder med H. Eksempelvis findes på Universitetsbibliotekets eksemplar af Utopia's 1691 udgave netop et skrevet H nederst på forsiden. Det er dog noget spidsere end H'et på U2 og kan måske læses som HE eller HF. 
Denne første præsentation af Flemming Pedersens bog løser ikke alle gåderne omkring de to Utopia'er. Men en stærk sammenhæng mellem de to bøger er evident. I hvert fald U2 har en nøje sammenhæng med Holbergs kilder. Udover de her beskrevne er der hundredevis af understregninger i U2, som man muligvis kan fralokke andre hemmeligheder. Gåden om Rasmus Andersön er ikke løst, og vi ved ikke, hvordan U2 har undgået brandene i 1728 og i 1813 .

Det kongelige Biblioteks Håndskriftafdeling har en mikrofilm af Flemming Pedersens bog; signatur: Ms. micro 3142. 